\title{
The Incidence of Capital Flight in an African Open Economy
}

\author{
Oluremi Ogun \\ University of Ibadan, Ibadan, Nigeria \\ Email: 1rogun@gmail.com
}

How to cite this paper: Ogun, O. (2017) The Incidence of Capital Flight in an African Open Economy. Open Access Library Journal, 4: e3736.

https://doi.org/10.4236/oalib.1103736

Received: June 11, 2017

Accepted: September 11, 2017

Published: September 14, 2017

Copyright ( 2017 by author and Open Access Library Inc.

This work is licensed under the Creative Commons Attribution International License (CC BY 4.0).

http://creativecommons.org/licenses/by/4.0/

\section{(c) (i) Open Access}

\begin{abstract}
This study investigated the incidence of capital flight in Nigeria. A combination of the push factors theory and the portfolio risk approach was employed. The policy and economic environments and political developments were suspected enabling factors. The analysis was confined to the short run in order to avoid the ambiguity inherent in the long run effects of some explanatory variables. Following from the preliminary data analysis, estimates were provided for non-ratio and ratio specifications. Whereas the overall goodness of fit was very impressive under the two specifications, particular variables' performances were somewhat converse. However, a common denominator emerged from the results to tip off policy direction.
\end{abstract}

\section{Subject Areas}

Monetary Economics

\section{Keywords}

Monetary Policy, International Factor Movements, Illegal Behavior and the Enforcement of Law

\section{Introduction}

The significance of capital flight in economic growth considerations stemmed from its perceived pernicious effect. Capital flight that could simply be defined in terms of movement of capital out of a country in response to events of economic consequence, penalized growth in the opportunity cost sense. Domestic investment hence, growth lost in any one period due to capital flight could hardly be recovered. In essence, at the expense of the originating country, capital flight financed growth in the country where it was domiciled. Additional concerns over the growth penalizing impact of capital flight had been raised in the 
possible rivalry in terms of size, with external debts of developing countries and the likelihood of the debts actually transforming to the flight funds; this thus heightened the danger of severe growth depression in these economies [1].

In Nigeria, capital flight averaged about 270 million naira in the 1960s falling to a negative of about 1.7 billion in the 1970s. It then rose to about 7.6 billion naira and 118 billion naira respectively in the next two decades before recording a negative of about 3 trillion naira in the decade of 2000-2010. Thus sequentially, it grew at an annual average rates of about 2 percent, -135 percent, 116 percent, 184 percent and -33 percent in the five decades ${ }^{1}$. In terms of significance, its proportion of the national product measured by the gross domestic product was successively about 9 percent, -5 percent, 12 percent, 12.5 percent and -17 percent. In a sense therefore, capital flight represented a significant command over economic resources in the Nigerian economy.

This paper reported the outcome of an investigation into the impact of macroeconomic factors on capital flight in Nigeria for the period, 1960 to 2010. As an economic entity, Nigeria had experimented with different economic philosophies (hence, policy regimes) and also experienced sharp fluctuations in economic growth with apparent implications for capital movement across its borders. The main contribution of the study was the underscoring of some trade and exchange rate allied factors as important determinants of capital flight in Nigeria; as opposed to conventional wisdom, there was only little evidence in support of the importance of both interest rate and inflation differentials in the study.

\section{The Economic and Policy Environments}

The review in this section covered only the period of reference in the study.

Up till about a decade after Nigeria's political independence in 1960, agriculture was the dominant economic activity accounting for not less than 60 percent of the GDP and employment. Export of agricultural products also constituted the major foreign exchange earner of the country. As the commodity export boom of the post-World War II had petered out by the early 1960s, the growth of economic activities could be described as modest between the 1960s and early 1970s.

A fixed exchange rate regime (marked by strict fixed parities with gold, US dollar and British pound sterling up till 1967) was in place and the policy stance was generally of the nature of economic regulation, hence, little or no surprises in economic prices were anticipated. By implication, there was reduced scope for speculative activities that could metamorphose into capital flight. However, between 1967 and 1971, there was evidence that the domestic currency had become overvalued with the country twice refusing to devalue in tandem successively with the British pound sterling and the American dollar to which its currency

${ }^{1}$ Whereas, the negative annual average growth rate recorded for the 1970s was accounted for by a sharp decline of about 480 percent in 1973 which drowned the other rates in the decade, that of the 2000-2010 decade was a reflection of the general trend. 
had been pegged [2]. This coupled with the outbreak of civil war in the late 1960 s and its expectations might have prompted some capital movements across the borders. However, such probable capital flights were never reported or regarded as major policy concerns.

The oil price shocks of the 1970s (1973 and 1977) appeared to have introduced a new dimension to economic permutations in the country as it transferred an unprecedented level of wealth (in the region of US $\$ 100$ billion between 1973 and 1980) to the economy [3]. The spending effect of the boom engendered a significant appreciation of the domestic currency causing the real exchange rate to fall mostly [4]. The currency appreciation encouraged a thriving business of parallel market exchange rate deals with the principal fallout being the emergence of foreign currency holding as an attractive portfolio choice. Meanwhile, the combined consequence of the spending and resource movement effects of the boom had been a shrunk tradable goods sector and an expanded nontradable goods sector. With the services sector accounting for not less than 60 percent of nontradables in the period, it is clear that there was an expanded scope for deals in foreign exchange during the boom.

Oil export receipts leveled off unexpectedly around 1981 leaving the country with an asymmetric growth structure with a declining domestic production and non-oil exports but growing imports and nontradable goods' sector. The culture of "easy money" planted during the boom period had shifted activities to the services sector that by 1985 accounted for about 32 percent of the country's GDP. Meanwhile, the combination of the inflexible fiscal policy stance of the government and the declining revenue profile had produced a tremendous expansion in imports and import payment arrears hence, external debt. Whereas, the import bill of the country rose from about 4 billion naira in 1975 to 10 billion naira in 1980, sliding to about 8 billion naira in 1985, external indebtedness grew unprecedentedly by about 76 percent in the first half of the 1980s to US $\$ 19.4$ billion in 1985. Thus, the economic situation and policies of the period might have been inadvertently pro-capital flight. The incidence might also have received a fillip from the fact that government agencies of the time were tardy at keeping records as the country could not with accuracy indicate/state the level of its actual foreign indebtedness. By 1987, the size of the external debt of the country had grown partly through rescheduling to about US $\$ 33$ billion!

Perhaps, an accurate indicator of the state of the economy and the development in its foreign exchange segment was the parallel market exchange rate premium. It experienced an average change of about 82 percent in the 1960s, slowing to about 14 percent in the succeeding decade of the 1970s. It maintained its positive growth at about 8 percent in the 1980s but accelerated by about 60 percent in the 1990s. It however decelerated by about 18 percent between 2001 and $2008^{2}$. Generally, the scope for profitable trade in foreign currency was wide and probably promoted a capital flight "round tripping" process.

${ }^{2}$ The parallel market exchange rate premium figures were computed as the percentage excess of the parallel market rate over the official or autonomous market rate as the case may be. 
The country introduced a structural adjustment program in September 1986, heralded by an auction market for exchange rate determination. However, the organized precursor debates on whether or not the country should take a loan from the International Monetary Fund as well as the expectations of the eventual affirmative policy action might have prepared the ground for massive ex post capital flight in the period. Apart from the incidence of capital flight contributing to the significantly upward direction of the recorded second-tier foreign exchange market and parallel market rates (via leads and lags for example), it could also have appeared in the garb of domestic prices of agricultural exports. "Reference [4] reported that the explosion in commodity export prices in the late 1980s was completely at variance with the direction of changes in the nominal and real exchange rates as well as the world prices of the commodities".

Policy uncertainty marked the period of the economic reforms in the country as the policy regime generally oscillated between regulated and deregulated. This was besides the general apprehension and uncertainty surrounding military rule under which the country was governed from 1966 to 1979 and 1983 to 1999. However, the regime of 1993 to 1998 was particularly draconian in policy orientations and general international economic and political relations causing many foreigners and indeed citizens to flee the country. Besides, as later investigations and fund repatriations were to suggest, huge sums of money was stashed away in foreign countries by the military rulers and their family members.

The civilian regime that was to succeed military rule in 1999 appeared to have restored investors' confidence as its economic policies were generally investor friendly. Coupled with a sense of prosperity influenced by a new round of oil export boom, a huge external debt cancellation, an unprecedented level of foreign reserves and a somewhat reversed negative cultural and nationalistic attitude that held sway under some of the military governments in the country, the tendency of Nigerians to migrate to other lands appeared significantly reduced. However, it was difficult to assert with confidence that all the succeeding governments sustained this trend.

\section{Linked Literature}

The literature reviewed below covered issues of significance, nature and definition, determinants and measurement and estimation approaches.

Capital flight represented one of the major economic problems of most developing economies could perhaps be associated with the backwardness experienced in such economies. "Reference [5] reported that Africa had a larger proportion of private wealth in overseas countries compared to other regions and equally had larger entries in the World Bank definition of countries characterized as severely indebted low-income countries". A study by [1] showed that this group of countries constituted the "net creditor" to the rest of the world in the sense that accumulated capital flight exceeded the stock of external debt.

In order to explain the nature of capital flight, a number of definitions had 
been proffered in many studies. For clarity of analysis, two strands of these definitions were maintained-determinants of capital flight and association of capital flight with macroeconomic policy outcomes. By cross examination, the determinants' literature emphasized more on identifying the variables that were responsible for capital flight in a country or a cross-section of countries. This literature however addressed the effect of macroeconomic policy outcomes on capital flight (for example, high budget deficits, high inflation rate, interest rate differentials, domestic tax and trade policies, and overvalued exchange rate) as significant determinants, see e.g. [6]-[11].

The other strand of literature on capital flight spotlighted the importance and often contemporaneous association between capital flight and other perverse macroeconomic outcomes such as low rates of growth [12], increased aid inflows [13], high external debt [8] [14] [15] and financial and currency crises [16]. Where the role of institutional factors was concerned, many economists and political scientists had long argued that there was a significant association between institutions and economic performance. "References [17] [18] and [19] identified the role and significance of institutions on particular macroeconomic outcomes such as volatility, crises, and growth". The authors however argued that some governments often chose a battery of inefficient microeconomic and macroeconomic policies and regulations to address the question of capital transfer.

Various approaches had been proposed to capture the content of the magnitude of capital flight and its effects on policy response to economic and political instability. Each method however differed conceptually as to what constitute capital flight based on the distinctions between "normal flows" and "capital flight", "short term" and "long term", "legal and illegal transactions". As a result, estimates of capital flight varied. There were five methods of measuring capital flight. These included: Hot money method, World Bank Residual method, Dooley Method, Trade mispricing method and Portfolio diversification method.

The "hot money" method summed up net errors and omissions and non-bank short-term capital flows [6]. "Reference [20] however criticized the hot money method for considering only short term capital outflows while ignoring longerterm outflows". The hot money measure captured the legal aspect of capital flight. "Reference [21] method distinguished between normal capital flows and abnormal capital flows". Based on this approach, the motive behind capital flight was the individual assumptions about the individuals' motives. Capital flight was therefore measured as the sum of externally held assets of the private sector that did not generate recorded income in the country's balance of payments. The "residual method" measured capital flight by comparing the sources of capital flows with the uses of these inflows. In other words, the amount by which capital inflows exceeded their uses constituted the residual approach to measuring capital flight ${ }^{3}$.

Capital flight based on the residual approach could equally be adjusted to ac-

${ }^{3}$ Variants of this approach included [22] [23]. 
commodate trade misinvoicing. Trade misinvoicing could either be in the form of under invoicing of exports and over invoicing of imports [24] [25]. The resultant adjusted capital flight was the sum of residual capital flight and trade misinvoicing. Trade misinvoicing was obtained by comparing trade data from both the importing and exporting countries. The combination of the World Bank Residual, Dooley and Trade mispricing methods captured the illegal aspects of the capital flight.

In terms of theoretical underpinning, portfolio choice decisions appeared to be the most popular, see e.g. [6] [7] [8]. From this perspective, profit maximizing investors would decide to invest outside the country when risk adjusted returns abroad were higher. Therefore, capital flight was seen as a response to changes in an individual's portfolio bundle arising from factors such as the fear of political and economic uncertainty. "Reference [26] added political economy considerations to the risk asymmetry view, suggesting that the incumbent government was happy to accumulate foreign debt since it did not internalize the burden that this would be placed on future (possibly rival) regimes and on future generations".

There were two main literature streams of estimating capital flight. First stream investigated the issue of capital flight as a portfolio diversification choice, made by each individual [27]. Second stream analyzed capital flight in terms of a country-distinct phenomenon. While the first stream of researches found evidence that the main determinants of capital flight were inflation rates and financial risks, the second stream found strong evidence in favor of political uncertainty [28].

One of the first attempts to measure the magnitude of capital flight in transition European countries was made by [27], who evaluated the capital flight for five countries in Central and Eastern Europe for the period of 1988-1993. "Reference [29] performed a wider analysis of twelve transition economies of Central and Eastern Europe for the period, 1995-2005". However, both papers concluded that the capital flight out of countries in transition was in line with the main explanation of capital flight, which was "driven by differences in interest rates and investors' expectations about future tax rates, inflation, etc. in their countries as well as by the ease with which they were able to transfer their wealth overseas". The most recent research was performed by [30] for the whole range of developing countries and countries in transition in 2002-2006. In all, the authors estimated capital flight using the Hot Money, the World Bank and Trade Mispricing measures. Their estimates of the capital flight for the developing countries were subsequently used to analyze the effect of capital flight on real economic growth.

There was a stream of research devoted to the analysis of foreign direct investment and capital flight issue as well as the determination of capital flight and its growth effect. For example, [31] performed factor analysis to see how capital flight cointegrated with other macroeconomic variables. He found that up to 
$40 \%$ of government-guaranteed external borrowings left the developing countries as capital flight. On the other hand, [32] used the endogenous growth models to establish the relationship between external debt, capital flight and some macroeconomic variables. Further, [33] used counterfactual calculations to find that capital flight reduced the economic growth of Philippines from 1 to 2.3 percent between 1970 and 1999.

Some empirical studies considered non-macroeconomic factors in capital flight analysis. In their cross-sectional examination of the link between political risk and capital flight for a number of developing countries, [28] concluded that no matter how capital flight was defined or measured, political risk factors had a significant role to play in its determination when no other macroeconomic variables were considered. Empirical support for this view existed in [34] for Latin American countries.

External debt had been hypothesized to impact on capital flight. In other words, countries had been borrowing and simultaneously engaging in capital flight. This was what [8] termed, debt-flight revolving door that was tested for Philippines with the result that external debt positively and significantly influenced capital flight. Similar results were obtained for a group of Sub-Saharan African countries [1], Turkey [15], and, India [14]

"Reference [35] examined the determinants of capital flight in seven Middle Eastern and North African (MENA) countries during the period of 1981-2008. Four econometric techniques were used". These were: Ordinary Least Squares, Fixed Effects, Random Effects and Seemingly Unrelated Regression Model. The empirical findings indicated that capital flight in MENA countries was driven mainly by lagged capital flight, external debt, foreign direct investment, real GDP growth rate and uncertainty.

"Reference [36] studied the determinants of capital flight in Bangladesh during 1973-1999 by applying the bounds testing and autoregressive distributed lag". Findings indicated that political instability was the most important factor affecting capital flight. Other factors such as: corporate income taxes, higher real interest rate differentials and lower GDP growth rates, proved to be significant. "Reference [37] examined the empirical determinants of China's capital flight during the period 1999-2008; in addition to the covered interest rate differential, their empirical exercise included a rather exhaustive list of macroeconomic variables and a few institutional factors". Overall, the regression analysis indicated that China's capital flight was quite well explained by its own history and covered interest differentials. The other possible determinants offered relatively small additional explanatory power.

Empirical as well as theoretical validations of macroeconomic factors influencing the magnitude of capital flight were rampant. "Reference [21] examined the relationship between inflation rate and capital flight for 5 Latin American countries between 1973 and 1986". He found a significant and positive relationship between inflation and capital flight. "Reference [38] formulated the hypothesis 
that inflation had a positive additional impact on post-war capital flight flows". He used four measures of capital flight in a panel data analysis of 77 developing countries between 1971 and 2000. His results consistently supported the hypothesis that post-war inflation exacerbated annual capital flight by about 0.005 to 0.01 percentage points of GDP. He further concluded that low inflation helped in dampening capital flight in post-conflict economies.

"Reference [6] employed time series analysis from 1974 to 1984 to verify the relationship between capital flight and a number of macroeconomic variables". His results showed that interest rate differentials, external debt flows, lagged capital flight, inflation and exchange rates significantly accounted for capital flight in 7 Latin American countries. Other empirical contributors included [8] who confirmed the contribution of external debt, budget deficits, and interest rates in the determination of capital flight. "Reference [10] validated external debt, real interest rates differentials and unemployment rate as the determinants of capital flight".

\section{Analytical Framework and Model}

Two approaches to analyzing the effect of macroeconomic factors on capital flight appeared popular. The first emphasized push factors which were usually fired by the desire to maximize the overall risk-adjusted return on portfolios. Macroeconomic policies inducing distortion in prices such as interest rate and exchange rate were usually focused [6] [39]. The time inconsistency problem in policy making could be contributory via inflation expectations. Also, lags in the demand for foreign currency could be a reflection of capital flight under this view.

The second emphasis was on the differences in the perceived risks of holding domestic assets vis-à-vis foreign assets or debt instruments. The expropriation risk associated with this approach resulted mostly from weak legal and institutional arrangements for protecting private property agents and high taxation fueled in part by expectations resulting from the consequences of default in situation of publicly guaranteed private holding of foreign debt. Thus, under this approach, capital tended to fly from investment markets perceived as risky (mostly, developing economies) to those markets with more secure and stable investment climate (mostly, the developed world) [40].

A combination of these two approaches appeared necessary to produce a balanced view of the influence of macroeconomic factors on capital flight. Thus, in the first instance, the model appeared as:

$$
\begin{array}{r}
\mathrm{KF}=\mathrm{f}\left(\mathrm{GDPG}, \mathrm{TD}, \mathrm{i}_{\mathrm{d}}-\mathrm{i}_{\mathrm{f}}, \pi^{*}, \pi_{\mathrm{d}}-\pi_{\mathrm{f}} \text {, RER, FD, PMP, INST, KC, ED, DMR }\right) \\
(-) \quad(-)(+)(+) \quad(+) \quad(+)(-) \quad(+) \quad(+)(+)(+)(+)
\end{array}
$$

where, KF was capital flight; GDPG was growth of gross domestic product (current prices); TD was trade deficit; $i_{d}-i_{f}$ was interest rate differential; $\pi^{*}$ was expected inflation; $\pi_{d}-\pi_{f}$ was inflation differential; RER was real exchange rate ${ }^{4}$;

${ }^{4}$ In a strict nominal expression, nominal exchange rate (NER) would take the place of RER. 
FD was fiscal deficit; PMP was parallel market exchange rate premium; INST was quality of institution and would be proxy by two variables-a dummy (INSTD), characterized by 1 for years of double digit inflation and 0 otherwise, (it should positively affect capital flight) and TES which reflected total expenditure on security (it should negatively affect capital flight); KC was capital control; ED was external debt and DMR was dummy variable capturing the effect of economic recession with 0 for normal years and 1 for recession years. DY captures expectations induced capital flight: a growing DY ratio raised expectations of future high taxation hence, supplying the motive for rising capital flight [5]. The signs under the variables were the corresponding partials ${ }^{5}$.

PMP was an indicator of policy distortion in the foreign exchange market and could be a proxy for degree of openness. It could also serve as a proxy for the incidence of corruption in the system. Thus, it could be interchanged or even combined with corruption perception index in the estimation. Quality of institution entered as a source of policy distortion, weak capacity for adequate and effective law and order as well as an evidence of weak regulatory capacity. Fiscal deficit ratio could be a proxy for macroeconomic instability. GDPG essentially captured the effect of economic prosperity and could also be expressed in terms of growth of GDP per capita (YPC). An alternative specification expressed the dependent variable and some independent variables as ratios of GDP. Thus:

$$
\begin{aligned}
& \text { KFY }=\mathrm{f}\left(\mathrm{GDPG}, \mathrm{TDY}, \mathrm{i}_{\mathrm{d}}-\mathrm{i}_{\mathrm{f}}, \pi^{*}, \pi_{\mathrm{d}}-\pi_{\mathrm{f}} \text {, RER, FDY, PMP, INST, KCY, DY, DMR }\right)
\end{aligned}
$$

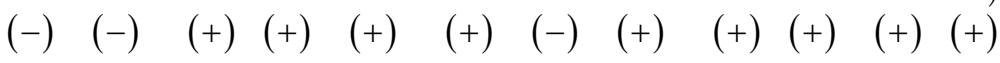

where, KFY was capital flight-GDP ratio, TDY was trade deficit ratio, FDY was fiscal deficit ratio, KCY was capital control ratio and DY was external debt ratio.

In log expressions, Equations (1) and (2) were adjusted to appear as:

$$
\begin{aligned}
\log \mathrm{KF}= & \alpha_{0}+\alpha_{1} \log \mathrm{GDPG}+\alpha_{2} \log \mathrm{TD}+\alpha_{3}\left(\mathrm{i}_{\mathrm{d}}-\mathrm{i}_{\mathrm{f}}\right)+\alpha_{4} \log \pi^{*}+\alpha_{5} \log \left(\pi_{\mathrm{d}}-\pi_{\mathrm{f}}\right) \\
& +\alpha_{6} \log \mathrm{RER}+\alpha_{7} \log \mathrm{FD}+\alpha_{8} \log \mathrm{PMP}+\alpha_{9} \log \mathrm{INSTD} \\
& +\alpha_{10} \log \mathrm{TES}+\alpha_{11} \log \mathrm{KC}+\alpha_{12} \log \mathrm{ED}+\alpha_{13} \mathrm{DMR}+\mu_{\mathrm{t}}
\end{aligned}
$$

where, $\mu_{t}$ was random error term.

$$
\begin{aligned}
\log \mathrm{KFY}= & \alpha_{0}+\alpha_{1} \log \mathrm{GDPG}+\alpha_{2} \log \mathrm{TDY}+\alpha_{3}\left(\mathrm{i}_{\mathrm{d}}-\mathrm{i}_{\mathrm{f}}\right)+\alpha_{4} \log \pi^{*}+\alpha_{5} \log \left(\pi_{\mathrm{d}}-\pi_{\mathrm{f}}\right) \\
& +\alpha_{6} \log \mathrm{RER}+\alpha_{7} \log \mathrm{FDY}+\alpha_{8} \log \mathrm{PMP}+\alpha_{9} \log \mathrm{INST} \\
& +\alpha_{10} \log \mathrm{TES}+\alpha_{11} \log \mathrm{KCY}+\alpha_{12} \log \mathrm{DY}+\alpha_{13} \mathrm{DMR}+\varepsilon_{t}
\end{aligned}
$$

where, $\varepsilon_{t}$ was error term.

\section{The Results and Interpretations}

This study was restricted to the short run in order to avoid the likely pitfalls inherent in the uncertainty over the direction of effect of possible long run variables. For example, growth of national income that should relieve the problem of capital scarcity and permits a more liberalized foreign exchange rate policy

${ }^{5}$ The negative sign under trade and fiscal deficits (and the eventual ratios) actually signified a positive effect on the dependent variable due to the natural sign of increases in these deficits and the allied ratios. 
stance would also imply an increase in wealth thereby creating the urge to see foreign portfolios as an attractive choice. A similar interpretation would apply in the case of sustained growth of exports. As a result, the study departed from the long run view of capital flight. In addition, the emphasis was on nominal capital flight in order to reasonably account for the influence of the price level and inflation differential. In this wise, nominal exchange rate (NER) was substituted for real exchange rate; the interpretation of the relevant coefficient remained the same ${ }^{6}$.

Ordinary least squares regression was employed in the study. In order to avoid the problem of spurious estimates, a unit root test was found necessary. The test conducted according to both the Augmented Dickey Fuller (ADF) and Phillips-Perron (PP) techniques produced the results in a Table 1 below $^{7}$. All variables were in logarithmic expression ${ }^{8}$.

From Table 1, the clear cut level stationary series were capital flight ratio (KFY), interest rate differential, inflation differential, trade deficit ratio and capital control. Domestic inflation was classed as I(1) even though stationary at $10 \%$. The problem with the $10 \%$ benchmark was that it often generated model

Table 1. Unit Root Tests.

\begin{tabular}{|c|c|c|c|c|c|}
\hline \multirow{2}{*}{ Variable } & \multicolumn{2}{|c|}{ Augmented Dickey-Fuller } & \multicolumn{2}{|c|}{ Phillips-Perron } & \multirow{2}{*}{ Remarks } \\
\hline & Level & First Difference & Level & First Difference & \\
\hline \multirow{2}{*}{ Capital Flight (KF) } & \multirow{2}{*}{$0.770(1.000)$} & $3.111(1.000)$ & \multirow{2}{*}{$-5.494(0.000)$} & \multirow{2}{*}{-} & \multirow{2}{*}{$\mathrm{I}(0) ?$} \\
\hline & & $-0.871(0.949)^{9}$ & & & \\
\hline Capital Flight Ratio (KFY) & $-4.207(0.000)$ & - & $4.150(0.010)$ & - & $\mathrm{I}(0)$ \\
\hline Gross Domestic Product (GDP) & $-2.4334(0.358)$ & $-5.5597(0.000)$ & $-2.473(0.339)$ & $-5.559(0.000)$ & $\mathrm{I}(1)$ \\
\hline Per Capita Income (PCY) & $-2.389(0.380)$ & $-5.566(0.000)$ & $-2.437(0.356)$ & $-5.566(0.000)$ & $\mathrm{I}(1)$ \\
\hline Interest Rate Differential (ITD) & $-6.354(0.000)$ & - & $-7.151(0.000)$ & - & $\mathrm{I}(0)$ \\
\hline Expected Inflation (Expinf) & $-3.486(0.053)$ & $-7.095(0.000))$ & $-3.340(0.073)$ & $-16.034(0.000)$ & I (1); I (0) at $10 \%$ \\
\hline Inflation Differential (Infdf) & $-3.665(0.034)$ & - & $-3.623(0.000)$ & - & I $(0)$ \\
\hline Trade Deficit (TD) & $-0.933(0.943)$ & $-8.020(0.000)$ & $-2.776(0.212)$ & $-16.451(0.000)$ & $\mathrm{I}(1)$ \\
\hline Trade Deficit Ratio (TDY) & $-5.133(0.000)$ & - & $-4.671(0.002)$ & - & $\mathrm{I}(0)$ \\
\hline Nominal Exchange Rate (NER) & $-1.855(0.662)$ & $-6.221(0.000)$ & $-1.873(0.653)$ & $-6.221(0.000)$ & $\mathrm{I}(1)$ \\
\hline Real Effective Exchange Rate (REER) & $-3.148(0.104)$ & $-5.352(0.000)$ & $-2.321(0.414)$ & $-5.230(0.000)$ & I (1) \\
\hline \multirow{2}{*}{ Fiscal Deficit (FD) } & \multirow{2}{*}{$16.557(1.000)$} & $2.446(1.000)$ & \multirow{2}{*}{$3.824(1.000)$} & $0.210(0.997)$ & \multirow{2}{*}{$\mathrm{I}(2)$} \\
\hline & & $-12.128(0.00)^{11}$ & & $-6.437(0.000)^{11}$ & \\
\hline Fiscal Deficit Ratio (FDY) & $-1.561(0.7928)$ & $-6.179(0.000)$ & $-3.651(0.035)$ & - & I (1) overall \\
\hline Parallel Market Exchange Rate Premium (PMP) & $-2.137(0.513)$ & $-6.306(0.000)$ & $-2.282(0.435)$ & $-6.405(0.000)$ & I (1) \\
\hline Capital Control (KC) & $-3.616(0.038)$ & - & $-3.653(0.035)$ & - & $\mathrm{I}(0)$ \\
\hline Capital Control Ratio (KCY) & $-2.184(0.487)$ & $-10.772(0.000)$ & $-3.379(0.065)$ & $-11.211(0.000)$ & I (1) \\
\hline External Debt (ED) & $-0.291(0.988)$ & $-5.346(0.000)$ & $-0.643(0.971)$ & $-5.338(0.000)$ & I (1) \\
\hline External Debt Ratio (DY) & $-0.434(0.983)$ & $-5.142(0.000)$ & $-0.703(0.967)$ & $-5.097(0.000)$ & $\mathrm{I}(1)$ \\
\hline Total Expenditure on Security (TES) & $-2.126(0.5190)$ & $-8.400(0.0000)$ & $-2.246(0.454)$ & $-8.274(0.000)$ & I (1) \\
\hline
\end{tabular}

Note: NA implies, not applicable; Source: Computed.

\footnotetext{
${ }^{6}$ The interpretation of the sign on NER required a great deal of care; where for example the exchange rate for a currency was quoted in pence/cent rate as in the case of Nigeria, a positive coefficient interpreted to mean a depreciation.

${ }^{7}$ All the data employed in the analysis were obtained from various issues of Statistical Bulletin published by the Central Bank of Nigeria and World Development Indicators published by The World Bank.

${ }^{8}$ The inflation variables in the models were in the cases of $\pi_{\mathrm{d}}$ and $\pi_{\mathrm{f}}$ generated as $\log$ differences of relevant consumer price indices while in the case of $\pi^{*}$, as the fitted series of a regression involving short run inflation determinants expressed in log. These explained the log prefixes.

${ }^{9}$ Second difference.
} 
instability in associated regressions. As a result, $5 \%$ was chosen as the highest benchmark in the study. Fiscal deficit was I(2) while all others were I(1). The order of integration of capital flight was based on only the PP test.

Results were produced for non-ratio and ratio specifications. In both cases, expected inflation generated from its short run determinants was excluded for reason of "near singular matrix". The results of the parsimonious model connected to the non-ratio specifications were as presented in Table 2 below ${ }^{10}$.

The two proxies for institution, INSTD and TES and their lags were deleted as demanded by the iteration process. Of the remaining variables, interest rate differential, inflation differential and the recession dummy (DMR) were incorrectly signed while all others conformed generally to a priori expectations and were

Table 2. Parsimonious Equation-Non-ratio Specifications.

Dependent Variable: LKF

Sample (adjusted): 19642010

Included observations: 47 after adjustments

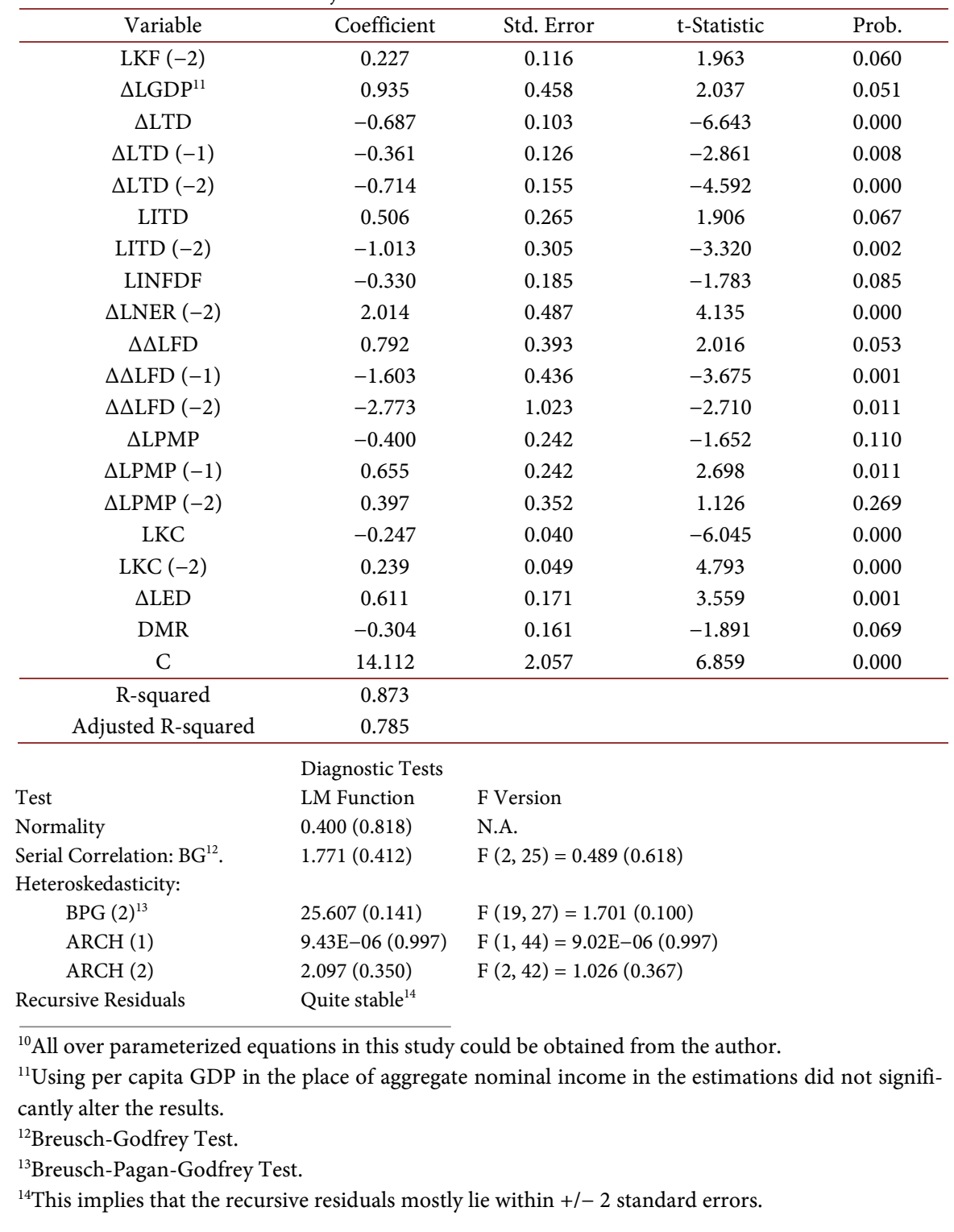


generally significant at the $5 \%$ level of testing ${ }^{15}$. It followed from this result that, growth of national income, trade deficit, fiscal deficit, nominal exchange rate depreciation, rising parallel market exchange rate premium, increasing capital control and growth of external debt strongly influenced capital flight in the period under consideration ${ }^{16}$. The result of interest rate differential suggested that it actually promoted capital inflow in the relevant period. Overall, the equation accounted for about $79 \%$ of the total variations in the dependent variable. The diagnostic tests suggested that the model was generally well behaved.

For the equation in which some variables (capital flight, fiscal deficit, trade deficit, capital control and external debt) were expressed as ratios of the gross domestic product, the results were presented in Table 3.

Table 3. Parsimonious Equation-Ratio Specifications.

Dependent Variable: LKFY

Sample (adjusted): 19642010

Included observations: 47 after adjustments

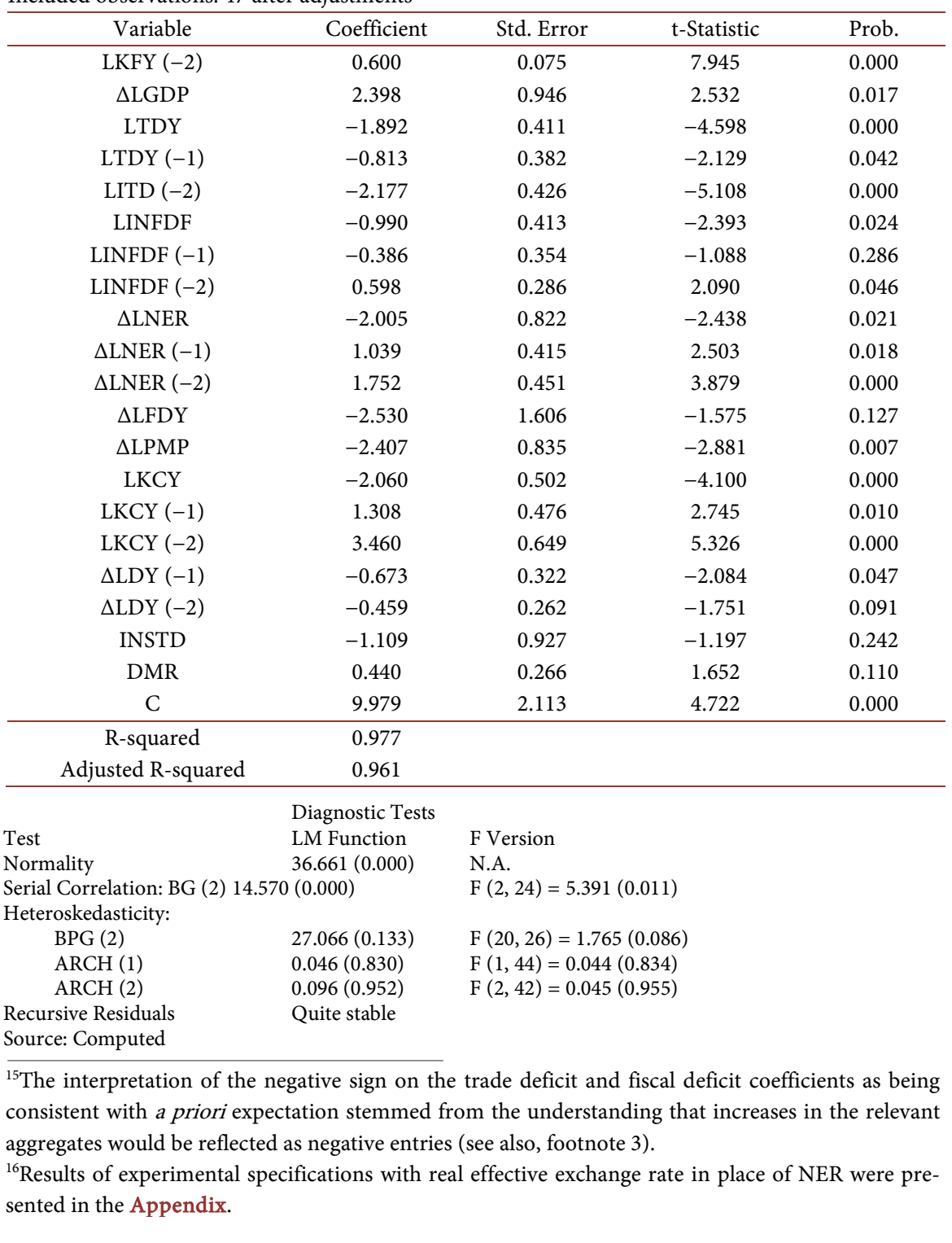


Of the two institutional' proxies (INSTD and TES), only INSTD survived the iteration and was correctly signed but insignificant even at $10 \%$. Also, variables such as gross domestic product, interest rate differential, inflation differential, parallel market exchange rate premium and external debt ratio were incorrectly signed though mostly significant. For contrast, lag of the dependent variable, trade deficit ratio, fiscal deficit ratio, nominal exchange rate changes, capital control ratio and the recession dummy bore the expected signs and were mostly significant. The equation explained over $96 \%$ of the variations in the dependent variable. However, the diagnostic tests cautioned on/against wholly adopting these results vis-à-vis those of the non-ratio counterpart.

\section{Conclusions}

This paper had been concerned with the incidence of capital flight in Nigeria. Results from the study suggested sensitivity of overall outcome to model specification. Whereas, the results of the model in which some variables were expressed as ratios of the gross domestic product performed relatively better in matter of coefficient of multiple determinations, the non-ratio expression model returned superior performance in terms of individual variable's significance and sign expectations. One result that stood out in the exercise was that irrespective of the form of variables' specification, variables such as trade deficit, nominal exchange rate and capital control were important determinants of short run capital flight in Nigeria. The course for policy was clearly suggestive.

In conclusion, it should be noted that the study was only concerned with the economic aspect of capital flight and did not capture political factors that might have played important roles. Besides, it was restricted to the short run and favored nominal measurement in order to accommodate some theoretically imposed limitations.

\section{References}

[1] Boyce, J. and Ndikumana, L. (2001) Is Africa a Net Creditor? New Estimates of Capital Flight from Severely Indebted Sub-Saharan African Countries, 1970-1996. Journal of Development Studies, 38, 27-56.

[2] Oyejide, T. (1985) Exchange Rate Policy for Nigeria: Some Options and Their Consequences. Proceedings of a One-Day Workshop, The Nigerian Economic Society, Management of Nigeria's Foreign Exchange Resources, 17-32.

[3] Ogun, O. (1993) Nigeria's Trade Policies During and After the Oil Boom: An Appraisal. In: Oyejide, T. and Obadan, M., Eds., Applied Economics and Economic Policy, Ibadan University Press, Ibadan, 198-222.

[4] Oyejide, T. and Ogun, O. (1995) Structural Adjustment and Exchange Rate Policy. In: Iwayemi, A., Ed., Macroeconomic Policy Issues in an Open Developing Economy. A Case Study of Nigeria, National Centre for Economic Management and Administration, Ibadan, 302-327.

[5] Collier, P., Hoeffler, A. and Pattillo, C. (2001) Flight Capital as a Portfolio Choice. World Bank Economic Review, 15, 55-80.

[6] Cuddington, J. (1986) Capital Flight: Estimates, Issues and Explanations. Princeton 
Studies in International Finance, No. 58.

[7] Lessard, D. and Williamson, J. (1987) The Problem and Policy Responses. In: Lessard, D. and Williamson, J., Eds., Capital Flight and Third World Debt, Institute for International Economics, Washington DC, 201-254.

[8] Boyce, J. (1992) The Revolving Door? External Debt and Capital Flight: A Philippine Case Study. World Development, 20, 335-349.

[9] Dooley, M. and Kletzer, K. (1994) Capital Flight, External Debt and Domestic Policies. Economic Review, Federal Reserve Bank of San Francisco No. 3.

[10] Henry, L. (1996) Capital Flight from Beautiful Places: The Case of Three Caribbean Countries. International Review of Applied Economics, 10, 263-272.

[11] Bhattacharya, R. (1999) Capital Flight under Uncertainty about Domestic Taxation and Trade Liberalization. Journal of Development Economics, 59, 365-387.

[12] Varman-Schneider, B. (1991) Capital Flight from Developing Countries. Westview Press, Boulder.

[13] Collier, P., Hoeffler, A. and Pattillo, C. (2004) Aid and Capital Flight. Oxford University: Centre for the Study of African Economies. http://users.ox.ac.uk/ ball0144/aid\&cf.pdf

[14] Chipalkatti, N. and Rishi, M. (2001) External Debt and Capital Flight in the Indian Economy. Oxford Development Studies, 29, 31-44. https://doi.org/10.1080/13600810124596

[15] Demir, F. (2004) A Failure Story: Politics and Financial Liberalization in Turkey, Revisiting the Revolving Door Hypothesis. World Development, 32, 851-869.

[16] World Bank (1998) World Development Report. World Bank, Washington DC.

[17] North, D. and Thomas, R. (1970) An Economic Theory of the Growth of the Western World. Economic History Review, 23, 1-17. https://doi.org/10.2307/2594560

[18] Bardhan, P. (1984) The Political Economy of Development in India. Basil Blackwell, Oxford.

[19] Acemoglu, D., Johnson, S., Robinson, J. and Thaicharoen, Y. (2003) Institutional Causes, Macroeconomic Symptoms: Volatility, Crises and Growth. Journal of Monetary Economics, 50, 49-123.

[20] Hermes, N., Lensink, R. and Murinde, V. (2002) Flight Capital and Its Reversal for Development Financing. UN-WIDER, Discussion Paper No. 99.

[21] Dooley, M. (1988) Capital Fight: A Response to Differences in Financial Risks. IMF Staff Papers, 35, 422-436. https://doi.org/10.2307/3867180

[22] World Bank (1985) World Development Report. World Bank, Washington DC.

[23] Erbe, S. (1985) The Flight of Capital from Developing Countries. Intereconomics, 20, 268-275. https://doi.org/10.1007/BF02925467

[24] Ndikumana, L. and Boyce, J. (2002) Public Debts and Private Assets: Explaining Capital Flight from Sub-N. Hermes Saharan African Countries. PERI Working Paper 32.

[25] Ndikumana, L. and Boyce, J. (2003) Public Debts and Private Assets: Explaining Capital Flight from Sub-Saharan African Countries. World Development, 31, 107-130.

[26] Alesina, A. and Tabelini, G. (1989) External Debt, Capital Flight and Political Risk. NBER Working Paper Series No. 2610.

[27] Sheets, N. (1995) Capital Flight from the Countries in Transition: Some Theory and Empirical Evidence. International Finance Discussion Papers 514. 
[28] Lensink, R., Hermes, N. and Murinde, V. (1998a) Capital Flight and Political Risk. Department of Economics, University of Groningen.

[29] Brada, J., Kutan, A. and Voksic, G. (2008) Capital Flight from Central and East European Countries: Estimates and Causes. EMG Working Paper WP-EMG-04-2008.

[30] Kar, D. and Cartwright-Smith, D. (2008) Illicit Financial Flows from Developing Countries: 2002-2006. Global Financial Integrity Report. http://www.gfip.com

[31] Kant, C. (1996) Foreign Direct Investment and Capital Flight. Princeton Studies in International Finance No. 80.

[32] Hadjimichael, M., Nord, R. and Ucer, M. (1994) Effect of Macroeconomic Stability on Growth, Savings and Investment: An Empirical Investigation. IMF Working Paper WP/94/98.

[33] Beja, E. (2007) Capital Flight and Economic Performance. MPRA Paper No. 4885.

[34] Fatehi, K. (1994) Capital Flight from Latin America as a Barometer of Political Instability. Journal of Business Research, 30, 187-195.

[35] Al-Fayoumi, N., Alzoubi, M. and Abuzayed, B. (2011) The Determinants of Capital Flight: Evidence from MENA Countries. International Business and Economic Research Journal, 11, 1-10. https://doi.org/10.19030/iber.v11i1.6666

[36] Alam, I. and Quazi, R. (2003) Determinants of Capital Flight: An Econometric Case Study of Bangladesh. International Review of Applied Economics, 17, 85-103. https://doi.org/10.1080/713673164

[37] Cheung, Y. and Qian, X. (2010) Capital Flight: China's Experience. Review of Development Economics, 14, 227-247. https://doi.org/10.1111/j.1467-9361.2010.00549.x

[38] Davies, V. (2004) Capital Flight and War. Centre for the Study of African Economies \& Department of Economics, University of Oxford.

[39] Rojas-Suarez, L. (1990) Risk and Capital Flight in Developing Countries. IMF Working Paper No. 90/64.

[40] Lensink, R., Hermes, N. and Murinde, V. (1998b) The Effect of Financial Liberalization on Capital Flight in African economies. World Development, 26, 1349-1368. 


\section{Appendix}

Table A1. Parsimonious Equation-Non-ratio Specifications (with REER).

Dependent Variable: LKF

Sample (adjusted): 19652010

Included observations: 46 after adjustments

\begin{tabular}{|c|c|c|c|c|}
\hline Variable & Coefficient & Std. Error & t-Statistic & Prob. \\
\hline $\operatorname{LKF}(-2)$ & 0.649 & 0.131 & 4.937 & 0.000 \\
\hline$\Delta \operatorname{LGDP}(-1)$ & -1.786 & 0.560 & -3.187 & 0.004 \\
\hline$\Delta \mathrm{LTD}$ & -0.278 & 0.112 & -2.474 & 0.020 \\
\hline$\Delta \operatorname{LTD}(-1)$ & -0.437 & 0.159 & -2.745 & 0.011 \\
\hline LITD & 1.117 & 0.408 & 2.737 & 0.011 \\
\hline $\operatorname{LITD}(-1)$ & -1.199 & 0.520 & -2.304 & 0.030 \\
\hline LITD (-2) & -0.666 & 0.422 & -1.579 & 0.127 \\
\hline LINFDF $(-2)$ & 0.369 & 0.213 & 1.729 & 0.096 \\
\hline$\triangle$ LREER & -1.934 & 0.637 & -3.035 & 0.005 \\
\hline$\triangle \operatorname{LREER}(-1)$ & 1.790 & 0.557 & 3.209 & 0.003 \\
\hline$\triangle \operatorname{LREER}(-2)$ & 2.056 & 0.622 & 3.305 & 0.003 \\
\hline$\Delta \Delta \operatorname{LFD}(-1)$ & -2.330 & 0.559 & -4.163 & 0.000 \\
\hline$\Delta \Delta \mathrm{LFD}(-2)$ & -6.771 & 1.270 & -5.331 & 0.000 \\
\hline$\triangle \mathrm{LPMP}$ & -1.416 & 0.457 & -3.097 & 0.004 \\
\hline$\Delta \operatorname{LPMP}(-1)$ & 0.538 & 0.408 & 1.316 & 0.200 \\
\hline$\triangle \operatorname{LPMP}(-2)$ & 1.074 & 0.396 & 2.712 & 0.012 \\
\hline LKC & -0.315 & 0.045 & -6.875 & 0.000 \\
\hline $\operatorname{LKC}(-2)$ & 0.435 & 0.066 & 6.510 & 0.000 \\
\hline$\triangle \mathrm{LED}$ & 0.569 & 0.201 & 2.831 & 0.009 \\
\hline$\triangle \operatorname{LED}(-2)$ & -0.412 & 0.219 & -1.877 & 0.072 \\
\hline DMR & -0.516 & 0.196 & -2.634 & 0.014 \\
\hline $\mathrm{C}$ & 5.777 & 2.153 & 2.682 & 0.013 \\
\hline R-squared & 0.860 & & & \\
\hline Adjusted R-squared & 0.738 & & & \\
\hline & Diagnostic Tests & \multirow{2}{*}{\multicolumn{2}{|c|}{ F-Version }} & \\
\hline Test & LM Function & & & \\
\hline Normality & $0.250(0.882)$ & \multicolumn{2}{|c|}{ Not Applicable } & \\
\hline Serial Correlation: BG (2) & $4.235(0.120)$ & \multicolumn{2}{|c|}{$\mathrm{F}(2,22)=1.115(0.345)$} & \\
\hline \multicolumn{5}{|l|}{ Heteroskedasticity: } \\
\hline BPG (2) & $20.917(0.464)$ & \multicolumn{2}{|c|}{$F(21,24)=0.953(0.541)$} & \\
\hline $\mathrm{ARCH}(1)$ & $1.339(0.247)$ & \multicolumn{2}{|c|}{$F(1,43)=1.319(0.257)$} & \\
\hline ARCH (2) & $3.392(0.183)$ & \multicolumn{2}{|c|}{$F(2,41)=1.712(0.193)$} & \\
\hline Recursive Residuals & Quite Stable & & & \\
\hline
\end{tabular}


Table A2. Parsimonious Equation-Ratio Specifications.

Dependent Variable: LKFY

Sample (adjusted): 19642010

Included observations: 47 after adjustments

\begin{tabular}{|c|c|c|c|c|}
\hline Variable & Coefficient & Std. Error & t-Statistic & Prob. \\
\hline $\operatorname{LKFY}(-2)$ & 0.784 & 0.090 & 8.635 & 0.000 \\
\hline$\Delta \mathrm{LGDP}$ & 1.707 & 0.934 & 1.827 & 0.078 \\
\hline LTDY & -1.245 & 0.407 & -3.057 & 0.004 \\
\hline $\operatorname{LTDY}(-1)$ & -1.394 & 0.469 & -2.972 & 0.006 \\
\hline $\operatorname{LTDY}(-2)$ & 0.827 & 0.439 & 1.883 & 0.070 \\
\hline $\operatorname{LITD}(-2)$ & -1.312 & 0.428 & -3.061 & 0.004 \\
\hline LINFDF & -1.576 & 0.326 & -4.824 & 0.000 \\
\hline $\operatorname{LINFDF}(-2)$ & 0.897 & 0.274 & 3.270 & 0.002 \\
\hline DLREER & -2.025 & 0.883 & -2.291 & 0.029 \\
\hline$\triangle \operatorname{LREER}(-1)$ & 2.091 & 0.586 & 3.564 & 0.001 \\
\hline$\Delta$ LFDY & -2.674 & 1.575 & -1.697 & 0.100 \\
\hline$\triangle \mathrm{LPMP}$ & -1.631 & 0.675 & -2.416 & 0.022 \\
\hline$\triangle \mathrm{LPMP}(-2)$ & -1.031 & 0.355 & -2.902 & 0.007 \\
\hline LKCY & -2.252 & 0.547 & -4.116 & 0.000 \\
\hline $\operatorname{LKCY}(-1)$ & 0.922 & 0.491 & 1.874 & 0.071 \\
\hline $\operatorname{LKCY}(-2)$ & 3.189 & 0.631 & 5.049 & 0.000 \\
\hline$\Delta \operatorname{LDY}(-1)$ & -0.864 & 0.326 & -2.650 & 0.013 \\
\hline DMR & 0.729 & 0.279 & 2.608 & 0.014 \\
\hline $\mathrm{C}$ & 5.558 & 2.064 & 2.691 & 0.011 \\
\hline R-squared & 0.975 & & & \\
\hline Adjusted R-squared & 0.960 & & & \\
\hline & Diagnostic Tests & & \\
\hline Test & LM Function & F-Vers & & \\
\hline Normality & $10.739(0.004)$ & \multicolumn{2}{|c|}{ Not Applicable } & \\
\hline Serial Correlation: BG (2) & $5.808(0.054)$ & \multicolumn{2}{|c|}{$F(2,26)=1.833(0.180)$} & \\
\hline \multicolumn{5}{|l|}{ Heteroskedasticity: } \\
\hline BPG (2) & $21.317(0.263)$ & \multicolumn{2}{|c|}{$\mathrm{F}(18,28)=1.291(0.265)$} & \\
\hline $\mathrm{ARCH} \quad(1)$ & $1.587(0.207)$ & \multicolumn{2}{|c|}{$\mathrm{F}(1,44)=1.573(0.216)$} & \\
\hline $\mathrm{ARCH} \quad(2)$ & $1.775(0.411)$ & \multicolumn{2}{|c|}{$\mathrm{F}(1,27)=8.072(0.008)$} & \\
\hline Recursive Residuals & Quite Stable & & & \\
\hline Source: Computed & & & & \\
\hline
\end{tabular}


Submit or recommend next manuscript to OALib Journal and we will provide best service for you:

- Publication frequency: Monthly

- 9 subject areas of science, technology and medicine

- Fair and rigorous peer-review system

- Fast publication process

- Article promotion in various social networking sites (LinkedIn, Facebook, Twitter, etc.)

- Maximum dissemination of your research work

Submit Your Paper Online: Click Here to Submit

Or Contact service@oalib.com 